\section{Cureus}

Received 01/14/2016

Review began 01/15/2016 Review ended 04/13/2016 Published 04/21/2016

\section{(c) Copyright 2016}

Liapis et al. This is an open access article distributed under the terms of the Creative Commons Attribution License CC-BY 3.0., which permits unrestricted use, distribution, and reproduction in any medium, provided the original author and source are credited.

\title{
Primary Malignant Melanoma of Renal Pelvis with Extensive Clear Cell Change
}

George Liapis ${ }^{1}$, Helen Sarlanis ${ }^{2}$, Elpida Poulaki ${ }^{1}$, Konstandinos Stravodimos ${ }^{1}$, Olga Riccioni 3 , Andreas C. Lazaris ${ }^{1}$

1. 1st Department of Pathology, School of Medicine, National and Kapodistrian University of Athens 2. Pathology, School of Medicine, National and Kapodistrian University of Athens, Athens, GRC 3. Medical School, La Sapienza University of Rome

$\square$ Corresponding author: Olga Riccioni, olga.riccioni@outlook.com Disclosures can be found in Additional Information at the end of the article

\section{Abstract}

Our presentation illustrates a rare case of primary renal pelvis malignant melanoma in a 35year-old man. The diagnosis of malignant melanoma was based on immunophenotype and the detection of intracellular melanin pigment. The renal origin was proven by the presence of scattered melanocytes within the urothelium of the pelvis. The tumor exhibited extensive clear cell change that closely mimics clear cell renal cell carcinoma. The patient's clinical history did not disclose any signs of previous melanocytic skin or mucosa lesions. Differential diagnosis includes tumors capable of synthesizing melanin or expressing melanocytic markers.

Categories: Pathology, Urology, Oncology

Keywords: clear cell, kidney, melanoma, pelvis, primary

\section{Introduction}

Primary malignant melanomas (MM) of the genitourinary tract constitute less than $1 \%$ of all MMs [1]. Primary melanoma of the kidney is an extremely rare type of tumor; only four cases of primary renal MM in adulthood have been described so far in the reviewed literature [2-5]. On the contrary, the kidney is often affected by metastatic melanoma mainly in the form of multiple cortical micrometastases [6] while renal pelvis involvement is usually secondary to a primary lesion of the posterior trunk [7].

Herein, we report a case of a 35-year-old man presenting with MM of the renal pelvis with extensive clear cell histological appearance. There was no clinical history of MM and no skin or mucosal lesions were found in the physical examination and endoscopy performed before and after diagnosis.

\section{Case Presentation}

A 35-year-old man was admitted to Laiko General Hospital due to macroscopic hematuria. A computed tomography (CT) scan revealed a mass of tumor that measured $2.5 \mathrm{~cm}$ in the largest diameter. The tumor was located in the pelvis of the right kidney. A nodular lesion that measured $3 \mathrm{~cm}$ in diameter was also found in the VII segment of the right liver lobe. The patient's previous clinical history was unremarkable, and his familial history did not disclose any relevant information. A right nephrectomy was performed, and a liver biopsy was obtained via surgical procedure. 


\section{Cureus}

A tumor measuring $2.5 \mathrm{~cm} \times 2.2 \mathrm{~cm} \times 2 \mathrm{~cm}$ was found in the renal pelvis protruding in the calyx and the peripelvic fat. The renal pelvis was partially obstructed. In cut sections, the tumor showed a solid texture with a whitish color. The rest of the kidney did not show any macroscopic lesions. The whole tumor as well as a liver biopsy specimen $1 \mathrm{~cm}$ in length were processed for histological examination according to the standard protocol. Formalin-fixed and paraffin-embedded tissue sections were prepared for light microscopy examination.

Immunohistochemical assays with antibodies for the detection of HMB-45, Melan-A, CD-10, WT-1, vimentin, pan-cytokeratin, SMA, chromogranin, synaptophysin, CD56 (DAKO, Glostrup, Denmark), and S-100 (THERMO SCIENTIFIC, Waltham, MA, USA) epitopes were performed under standard protocols in tumor tissue sections.

The examined pelvic tumor exhibited marked heterogeneity on histological grounds. The predominant pattern was composed of sheets or nests of clear cells separated by thin fibrous septa. Cells exhibited micro-vacuolated cytoplasm and round nuclei with indistinct nucleoli (Figure 1A). A secondary tumor component was also identified, characterized by confluent nests and sheets of round basophilic cells with chromatin-dense nuclei in an abrupt transition to the clear cell element (Figure 1B). Mitoses were numerous in the latter tumor area. Intranuclear inclusions were occasionally noted while melanin pigment deposition was also recognizable in a few areas (Figure 1C). Nests of tumor cells were also encountered within and beneath the urothelium with a resemblance to nevoid melanoma (Figure 1D).
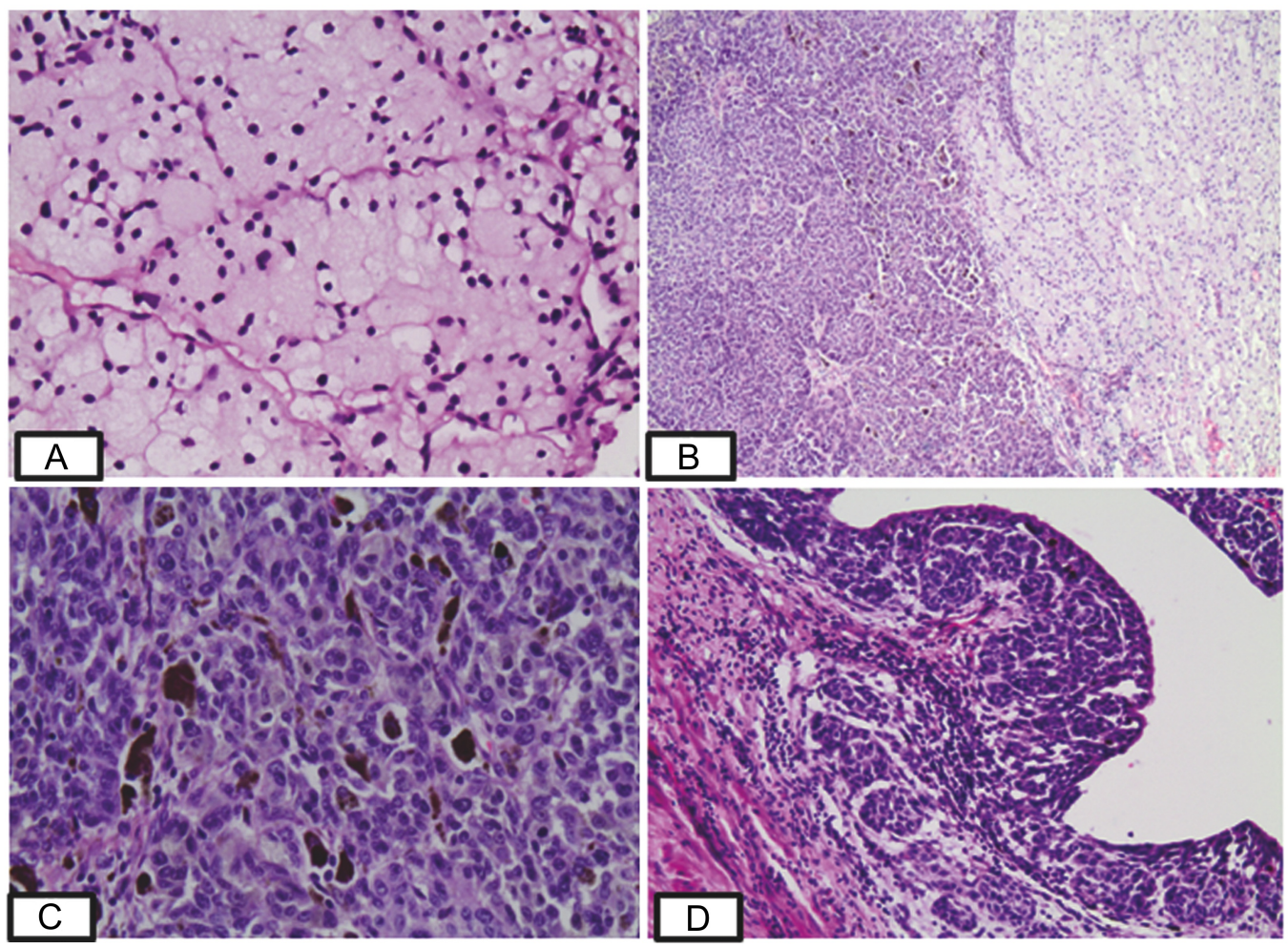

\section{FIGURE 1: H\&E staining of the pelvic tumor.}

A: Neoplastic cells with clear cytoplasm arranged in nests separated by thin fibrous septa (400x). B: Sheets of basophilic round cells in abrupt transition to the clear cell component (100x). C: Basophilic round cells, higher magnification. Melanin pigment is demonstrated (200x). D: Nests of tumor cells within and beneath the urothelium having a resemblance with "nevoid melanoma" (200x). 


\section{Cureus}

Biopsy material revealed metastatic infiltration of the liver tissue by the clear cell component of the renal tumor.

A positive reaction was seen for all melanocytic markers (HMB-45 (Figure 2A), S-100, Melan-A, and cytoplasmic reaction for WT-1) both in renal tumor and liver lesion. CD10, a marker of renal clear cell carcinoma that can also be expressed in melanoma [8], was positive in our case. Vimentin was also positive, while pan-cytokeratin, SMA, and the neuroendocrine markers chromogranin, synaptophysin, and CD56, were negative. Surprisingly, melanocytic markers revealed the presence of melanocytes within the urothelium, even in areas considerably distant from the main tumor (Figure $2 B$ ).
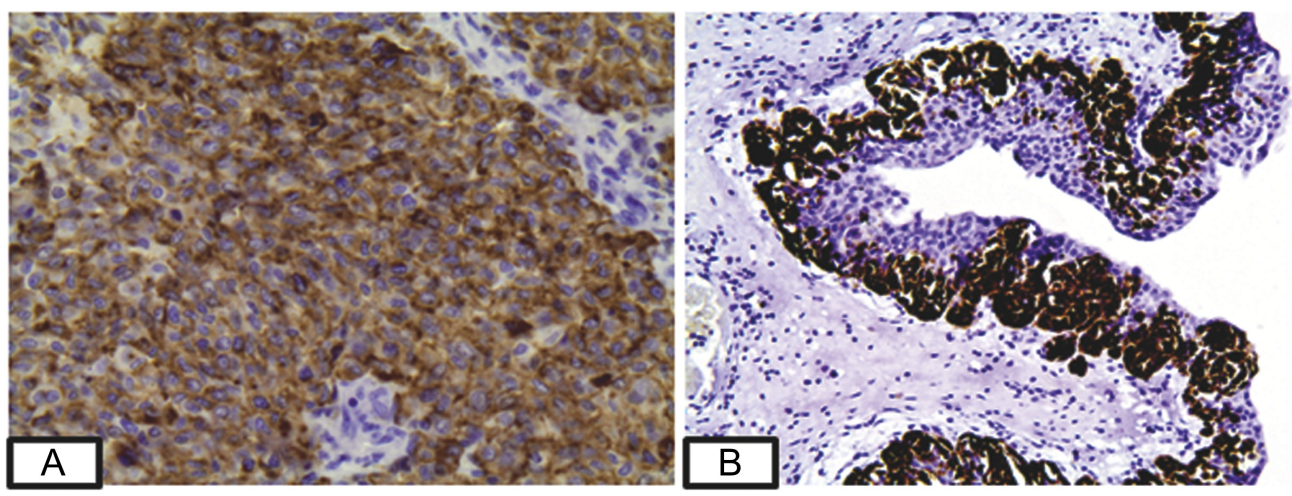

FIGURE 2: HMB-45 staining of the pelvic tumor.

A: Diffuse expression of HMB-45 in tumor cells (400x). B: Presence of melanocytes within the urothelium highlighted by HMB-45 (200x).

The final histological diagnosis was primary renal pelvis MM. The diagnosis was based on the detection of intracellular melanin pigment and the tumor immunophenotype while the renal origin was supported by the presence of melanocytes within the urothelium of the pelvis and by the exclusion of any primary melanocytic lesions of the skin or mucosal tissues. The liver nodule was considered metastatic.

After six months and under chemotherapy, a metastatic mass in the spleen was diagnosed via CT scan examination.

\section{Materials and methods}

Upon contact with the patient and approval of the Bioethics Committee of the Clinicolaboratory Sector, School of Medicine, The National and Kapodistrian University of Athens, the present case material was retrieved from the archive of the First Department of Pathology so that this report is made.

\section{Discussion}

We present the 5 th case of primary renal MM in adulthood. Table 1 presents information regarding the cases reported to date, including patient presenting symptoms and medical history, imaging and examinations results, surgical procedure, macroscopic findings, histological and immunohistochemical data, and follow-up. 


\section{Cureus}

\begin{tabular}{|c|c|c|}
\hline & Frasier et al. 1988 [3] & Tajima et al. 1997 [4] \\
\hline Patient & 37-year-old white man & $\begin{array}{l}\text { 74-year-old Japanese } \\
\text { woman }\end{array}$ \\
\hline Presenting symptoms & Gross hematuria and right flank pain & Pollakisuria \\
\hline \multicolumn{3}{|l|}{ Investigations } \\
\hline Abdominal CT & $\begin{array}{l}\text { Rounded, soft tissue mass confined } \\
\text { to the right renal pelvis; no evidence } \\
\text { of visceral metastasis }\end{array}$ & $\begin{array}{l}\text { Right renal mass with } \\
\text { irregular internal density; } \\
\text { no evidence of visceral } \\
\text { metastasis }\end{array}$ \\
\hline Physical examination & $\begin{array}{l}\text { Right flank and costovertebral angle } \\
\text { tenderness }\end{array}$ & $\begin{array}{l}\text { Unremarkable findings; } \\
\text { no skin lesions }\end{array}$ \\
\hline Urinalysis & Full field of red blood cells & $\begin{array}{l}\text { Slight microscopic } \\
\text { hematuria }\end{array}$ \\
\hline Surgical procedure & Nephroureterectomy & $\begin{array}{l}\text { Right radical } \\
\text { nephrectomy }\end{array}$ \\
\hline Macroscopic findings & $\begin{array}{l}\text { Tumor of about } 5.0 \times 4.0 \times 3.0 \mathrm{~cm} \text {, } \\
\text { feeling the entire renal pelvis, } \\
\text { without extending into the renal } \\
\text { parenchyma }\end{array}$ & $\begin{array}{l}\text { Solid tumor of about 3- } \\
3.5 \mathrm{~cm} \text {, showing a dark } \\
\text { brown color }\end{array}$ \\
\hline
\end{tabular}

Evaluation of the surgical specimins
Organized nest of markedly

pleomorphic cells with abundant

eosinophilic cytoplasm and large

Histology

hyperchromatic nuclei; isolated

areas with fine dust-like golden

pigment within the cytoplasm of

tumor cells. Tumor invasion into the

smooth muscle of the renal pelvis
Positivity for: S-100 protein, and stains for melanoma antigens.
Immunohistochemistry
Bayazit et al. 2002 [5]

37-year-old male

Localized, dull, right lumbar

pain

$\begin{array}{ll}\text { 7-cm heterogenic mass in the } & \text { Right renal mass with } \\ \text { right kidney; 3-cm lesion within } & \text { irregular internal density } \\ \text { the paracaval area extending } & \text { no evidence of visceral } \\ \text { towards the adrenal gland } & \text { metastasis }\end{array}$

$7-8-\mathrm{cm}$ mobile mass in the right

upper quadrant of the

abdomen; no skin lesion

Radical nephrectomy with
adrenalectomy, Paracaval and
interaortacaval lymph node
dissection

dissection

Right radical

nephrectomy

Slight microscopic

hematuria

Right radical
nephrectomy

Mass of about $4.5 \mathrm{~cm}$,

showing areas of focal

hemorrhage

Unremarkable findings:

no skin lesions

Unremarkable findings;

no skin lesions

(Macroscopic hematuria as presenting symptom)

Right

nephrectomy, Liver

biopsy obtained during

surgical procedure

Tumor of about

$2.5 \times 2.2 \times 2 \mathrm{~cm}$ in the

renal pelvis, protruding

in the calyx and the

peripelvic fat

Tumor marked

heterogeneity;

cells showing nodular

Extensive proliferation

of mainly clear cells;

brown pigment deposits

in the cytoplasm of the

tumor cells
Tumor composed of epitheloid

architecture; prominent melanin

pigmentation in the cytoplasm

of the tumor cells and stroma.

Tumor invasion into the

adjacent fatty tissue.

Metastases in the paracaval

lymph nodes

predominant pattern

composed of nests of

clear cells with micro-

vacuolated cytoplasm

and round nuclei;

melanin pigment

deposition in few areas.

Nests of tumor cells

within and beneath the

urothelium. Metastatic

infiltration of liver tissue

Positivity for: HMB-45,

S-100, Melan-A, WT-1,

CD10, and Vimentin

Positivity for: HMB-45, and Positivity for: HMB-45, 


\section{Cureus}

\begin{tabular}{|c|c|c|c|c|c|}
\hline & $\begin{array}{l}\text { Negativity for: iron stains, and } \\
\text { keratine stains }\end{array}$ & $\begin{array}{l}\text { specific enolase, and } \\
\text { HMB-45 }\end{array}$ & Fontana-Masson stain & and S-100 protein & $\begin{array}{l}\text { cytokeratin, SMA, } \\
\text { Chromogranin, } \\
\text { Synaptophysin, and } \\
\text { CD56 }\end{array}$ \\
\hline Treatment & $\begin{array}{l}\text { Bacuiillus Calmette-Guerin and } \\
\text { allogenic melanoma cell vaccination } \\
\text { protocol as adjuvant immunotherapy } \\
\text { regimen }\end{array}$ & $\begin{array}{l}\text { Human } \\
\text { lympfoblastoidinterferon- } \\
\text { alfa therapy; interruption } \\
\text { after } 1 \text { month (due to } \\
\text { patient's general fatigue } \\
\text { and appetite loss) }\end{array}$ & $\begin{array}{l}\text { Fotemustine and interferon-alfa } \\
2 b \text { therapy for } 3 \text { months (in } \\
\text { another institution) }\end{array}$ & $\begin{array}{l}\text { Human } \\
\text { lympfoblastoidinterferon- } \\
\text { alfa therapy; interruption } \\
\text { after } 1 \text { month (due to } \\
\text { patient's general fatigue } \\
\text { and appetite loss) }\end{array}$ & Chemotherapy \\
\hline Follow-up & $\begin{array}{l}1 \text { year after initial presentation: } \\
\text { recurrence at surgical incision } \\
\text { treated by wide excision. } 22 \text {-month } \\
\text { follow-up: no evidence of disease }\end{array}$ & $\begin{array}{l}2 \text { years and } 3 \text { months } \\
\text { after surgery: no } \\
\text { evidence of residual } \\
\text { disease }\end{array}$ & $\begin{array}{l}1 \text { year later (on his second } \\
\text { admission): neoplastic lesions } \\
\text { in the right nephrectomy space, } \\
\text { in the liver right lobe and in the } \\
\text { lung, detected via CT. } \\
\text { Urooncology follow-up care (he } \\
\text { refused chemotherapy) until he } \\
\text { died (because of respiratory } \\
\text { problems) }\end{array}$ & & $\begin{array}{l}\text { 6-month followup: } \\
\text { metastatic mass in the } \\
\text { spleen detected via CT }\end{array}$ \\
\hline
\end{tabular}

TABLE 1: Clinicopathologic features of primary renal MM cases reported in adulthood to date.

Most MMs of the kidney are metastatic, thus, a careful examination of histological features in combination with the evaluation of clinical data and CT scans is demanded. Differential diagnosis includes tumors capable of producing melanin and/or expressing melanocytic markers such as melanin-pigmented renal cell carcinoma [9], melanin-producing perivascular epithelioid cell tumor (PEComa) [10] and X11 translocation renal cell carcinoma [11]. Moreover, renal pelvis melanoma may show clear cell appearance mimicking conventional clear cell carcinoma [12]. Melanin-pigmented renal cell carcinoma is negative for melanocytic markers while the cytoplasm of tumor cells is clear. Furthermore, positivity of CD10 and vimentin in tumor cells does not aid in differential diagnosis between these two distinct entities. PEComa is negative for S-100 and positive for SMA. X11 translocation renal cell carcinoma may express Melan-A, but the histological features are different [11]. In addition, tumors showing a wide histological spectrum (such as Wilms tumor and clear cell sarcoma) may enter the differential diagnosis. However, tumor cell immunophenotype and melanin pigment deposition are opposed to both diagnoses.

The origin of the tumor is still obscure because the kidney is devoid of melanocytes [13]. Regarding the pathogenesis of urogenital melanoma in general, it is speculated that migrating precursor melanocytes from the neural crest may be the source of origin [14]. The established criteria for defining primary melanoma of the bladder $[15,16]$ may be also applied for the identification of the primary origin of renal pelvis melanoma. The following criteria are suggested: no previous cutaneous lesion history or any evidence of regressed cutaneous melanoma; no evidence of visceral melanoma in other parts; the pattern of recurrence should be consistent with the primary lesion; and the urothelium should contain atypical melanocytes or in situ melanoma at the vicinity of melanoma mass. 


\section{Conclusions}

In conclusion, our presentation illustrates a rare case of renal pelvis melanoma. It poses malignant melanoma as a potential differential diagnosis for renal tumors capable of synthesizing melanin or expressing melanocytic markers, especially considering the new entities that have been described such as X11 translocation renal cell carcinoma. The extensive clear cell histological appearance, closely mimics conventional renal clear cell carcinoma. A unique feature not mentioned in previous studies, is the presence of scattered melanocytes within the urothelium.

\section{Additional Information \\ Disclosures}

Human subjects: Consent was obtained by all participants in this study. Conflicts of interest: In compliance with the ICMJE uniform disclosure form, all authors declare the following: Payment/services info: All authors have declared that no financial support was received from any organization for the submitted work. Financial relationships: All authors have declared that they have no financial relationships at present or within the previous three years with any organizations that might have an interest in the submitted work. Other relationships: All authors have declared that there are no other relationships or activities that could appear to have influenced the submitted work.

\section{References}

1. Gupta R, Bhatti SS, Dinda AK, et al.: Primary melanoma of the urethra: a rare neoplasm of the urinary tract. Int Urol Nephrol. 2007, 39:833-6.

2. Tasdemir C, Turkmen ES, Dogan M, et al.: Primer malignant melanoma of kidney: a case report. Eur Rev Med Pharmacol Sci. 2011, 15:971-2.

3. Frasier BL, Wachs BH, Watson LR, et al.: Malignant melanoma of the renal pelvis presenting as a primary tumor. J Urol. 1988, 140:812.

4. Tajima K, Saito K, Umeda Y, et al.: Malignant melanoma of the kidney presenting as a primary tumor. Int J Urol. 1997, 4:94-6.

5. Bayazit Y, Aridoğan IA, Zeren S, et al.: Primary malignant melanoma of the kidney . Scand J Urol Nephrol. 2002, 36:77-9.

6. Fujimoto H, Chitose K, Tobisu K, et al.: Solitary renal melanoma? A case with long survival after initial treatment. J Urol. 1995, 153:1887-9.

7. Pinto F, Cappa E, Brescia A, et al.: Metastasis to the renal hilum from malignant melanoma of the anterior trunk: an unusual finding. Arch Ital Urol Androl. 2010, 82:119-21.

8. Oba J, Nakahara T, Hayashida S, et al.: Expression of CD10 predicts tumor progression and unfavorable prognosis in malignant melanoma. J Am Acad Dermatol. 2011, 65:1152-60.

9. Rossi G, Cadioli A, Costantini M, et al.: Heavily pigmented renal cell carcinoma: a case report, with review of the literature and differential diagnosis. Int J Surg Pathol. 2009, 17:167-9.

10. Fukunaga M, Harada T: Pigmented perivascular epithelioid cell tumor of the kidney . Arch Pathol Lab Med. 2009, 133:1981-4.

11. Argani P, Aulmann S, Karanjawala Z, et al.: Melanotic Xp11 translocation renal cancers: a distinctive neoplasm with overlapping features of PEComa, carcinoma, and melanoma. Am J Surg Pathol. 2009, 33:609-19.

12. Ehara H, Takahashi Y, Saitoh A, et al.: Clear cell melanoma of the renal pelvis presenting as a primary tumor. J Urol. 1997, 157:634.

13. Birkhoff JD, Lavengood RW Jr, Habif DV Jr, et al.: Hematuria and pleural effusion following parotid tumor. Urology. 1980, 15:194-8.

14. Mihajlovic $\mathrm{M}$, Vlajkovic $\mathrm{S}$, Jovanovic $\mathrm{P}$, et al.: Primary mucosal melanomas: A comprehensive review. Int J Clin Exp Pathol. 2012, 5:739-753.

15. Ainsworth AM, Clark WH, Mastrangelo M, et al.: Primary malignant melanoma of the urinary bladder. Cancer. 1976, 37:1928-36.

16. Stein BS, Kendall AR: Malignant melanoma of the genitourinary tract . J Urol. 1984, 132:859- 
Cureus

68. 